\title{
Prevalence and Risk Factors Associated with Insomnia Symptoms Among the Chinese General Public After the Coronavirus Disease 2019 Epidemic Was Initially Controlled [Corrigendum]
}

Guo J, Yang L, Xu Y, et al. Nat Sci Sleep. 2021;13:703-712.

The authors have advised affiliations 2 and 5 on page 703 is incorrect. The correct affiliations should read “2Guangdong-Hong Kong-Macao Greater Bay Area Center for Brain Science and Brain-Inspired Intelligence, Southern Medical University, Guangzhou, Guangdong,
People's Republic of China” and "55uangdong Mental Health Center, Guangdong Provincial People's Hospital, Guangzhou, People's Republic of China”.

The authors apologize for this error.

\section{Publish your work in this journal}

Nature and Science of Sleep is an international, peer-reviewed, open access journal covering all aspects of sleep science and sleep medicine, including the neurophysiology and functions of sleep, the genetics of sleep, sleep and society, biological rhythms, dreaming, sleep disorders and therapy, and strategies to optimize healthy sleep.
The manuscript management system is completely online and includes a very quick and fair peer-review system, which is all easy to use. Visit http://www.dovepress.com/testimonials.php to read real quotes from published authors. 